\title{
付帯柱のない RC 耐震壁の高精度曲げ解析法と限界曲率の略算法 SOPHISTICATED BENDING ANALYSIS AND SIMPLIFIED ESTIMATION OF ULTIMATE CURVATURE FOR RC SHEAR WALLS WITHOUT BOUNDARY COLUMN
}

\author{
山本直 樹*, 真田靖士** \\ Naoki YAMAMOTO and Yasushi SANADA
}

\begin{abstract}
This paper investigates the flexural performance of a typical shear wall with no boundary column through experimental, numerical and theoretical approaches, as follows:

1. The specimen failed in a brittle manner with concrete crushing at the bottom with a height of 2.5 times as the thickness.

2. Hinge length on the tensile side of the specimen was higher than that on the compressive side, which was considered in a bending analysis proposed in the paper.

3. The proposed analytical method evaluated the flexural performance of the specimen well.

4. Simple equations were derived to evaluate the flexural deformation capacity of this type of wall.
\end{abstract}

Keywords : Bending analysis, Ductility, Plastic hinge, Pushover test, Reinforced concrete, Structural wall 曲げ解析, 勒性, 塑性ヒンジ, 押切載荷実験, 鉄筋コンクリート, 構造壁

\section{1. はじめに}

耐震壁の設計自由度が 2010 年の鉄筋コンクリート（以下， RC) 構造計算規準・同解説 1)の改定によって大きく拡大された。本改定 により耐震壁の端部に付帯柱を設けない設計が可能となり，空間の 有効活用, 施工の合理化などが期待される。一方で, 付帯柱が省略 された耐震壁は, 従来の耐震壁に比べ, 壁端部のコンクリートが大 きな圧縮応力を負担するため, 壁端部の曲げ圧縮破壊により耐震壁 が脆性的な破壞性状を示すおそれがある。特に, 2010 年に発生した チリマウレ地震 2)では, この種の破壊形式により大きな被害を受け た RC 建物が数多く報告された。こうした背景の下, 筆者らの既往 の研究 3)では, 曲げ圧縮破壊する耐震壁の従来および近年の研究動 向を概説するとともに, 十数体の付帯柱がない耐震壁試験体の実験 結果を統計的に分析し, 圧縮側端部の応力状態や構造詳細と曲げ変 形性能の関係に支配的な因子を実験的に抽出した。しかし，こうし た変形性能一の影響因子の力学的根抛影響機構については必ずし も明確に説明されておらず, その結果, 実験データを補足する解析 的な資料の整備は難しい状況にある。従って, この種の耐震壁の曲 げ変形性能を評価するため, 変形性能を支配する機構の解明, 機構 に立脚した変形性能の評価法の構築が待たれる。

そこで, 本研究では付帯柱がない耐震壁が曲げ圧縮破壊する挙動 の基礎的な特性を把握するため，この種の耐震壁の押切載荷実験を 実施した ${ }^{4)}$ 。本稿では, 実験より得られた破壊挙動に基づいて, そ の曲げ変形性能を解析的に評価することを目的に，精微な曲げ解析
法を構築し，その有效性を検証する。さらに，本解析手法に基づい て, 付帯柱がない耐震壁の曲げ圧縮破壊の力学的機構を明らかにし て, 曲げ変形性能評価法を提案する。本論文では上記の研究成果に ついて報告する。

\section{2. 圧縮側に付帯柱がない耐震壁の押切載荷実験 4 \\ 2. 1 試験体計画}

実験に用いた試験体は文献 5)で設計された中高層 $\mathrm{RC}$ 建物の連層 耐震壁脚部を模擬した縮尺 1/2.5 の壁板片側に付帯柱がない試験体 である。同文献で繰り返し載荷実験が実施された試験体 $\mathrm{N}$ と同一の 構造詳細を有するが, 本研究のため別途製作した別の個体である(以 下， $\mathrm{N}(\mathrm{P})$ と称する)。試験体の立面および平面の配筋図を Figs.1, 2 に，構造諸元を Table1 に示す。壁高さは $1,200 \mathrm{~mm}$ ，壁長さは片側 の付帯柱も含めて $1,740 \mathrm{~mm}$ である。付帯柱のない壁端部には拘束 域が設けられた。拘束域長さは文献 5)の式(1)より評価した中立軸深 さに基づき，同程度の長さを確保した（Fig.3）。

$$
x_{n}=\frac{N+\sum a_{t} \sigma_{y}-\sum a_{c} \sigma_{y}}{0.85 \beta \cdot f_{c}^{\prime} \cdot t}
$$

ここで， $x_{n}$ : 圧縮縁からの中立軸深さ, $N$ : 長期軸力, $a_{t}, a_{c}$ : 引張, 圧縮鉄筋断面積, $\sigma_{y}$ : 鉄筋降伏強度, $\left.\beta: \mathrm{ACI} 318^{6}\right)$ による低減係数, $f_{c}{ }^{\prime}$ : コンクリート圧縮強度, $t$ : 壁厚である。ただし, 同式では $x_{n}$ の 算定過程において $a_{t}, a_{c}$ の仮定が必要なため, 繰り返し計算を要す る旨を補足する。
* 大阪大学大学院工学研究科地球総合工学専攻 元大学院生

** 大阪大学大学院工学研究科地球総合工学専攻 准教授. 博士 (工学)
Former Grad. Stud., Div. of Global Architecture, Graduate School of Eng., Osaka University Assoc. Prof., Div. of Global Architecture, Graduate School of Eng., Osaka University, Dr.Eng. 
Table1 Details of $N(P)$ specimen

\begin{tabular}{|c|c|c|c|c|c|}
\hline \multirow{3}{*}{$\begin{array}{l}\text { Boundary } \\
\text { column }\end{array}$} & $\mathrm{B} \times \mathrm{D}$ & $300 \mathrm{~mm} \times 300 \mathrm{~mm}$ & \multirow{6}{*}{ Confined area } & Long. rebar & 10-D10 \\
\hline & Long. rebar & 12-D16 (2.65\%) & & Horizontal bar & D4@35 double (0.67\%) \\
\hline & Hoop & D4@35 (0.27\%) & & Cross-tie & D6@35 (1.09\%) \\
\hline \multirow{3}{*}{ Wall } & Thickness $t$ & $120 \mathrm{~mm}$ & & \begin{tabular}{|l} 
Shape of cross-tie \\
\end{tabular} & $90^{\circ}$ and $135^{\circ}$ end hooks \\
\hline & Vertical bar & D4@100 double (0.23\%) & & Length & $393 \mathrm{~mm}$ \\
\hline & Horizontal bar & D4@35 double (0.67\%) & & Height & $1,200 \mathrm{~mm}$ \\
\hline
\end{tabular}

図中の括弧内の数值は鉄筋比を表す。

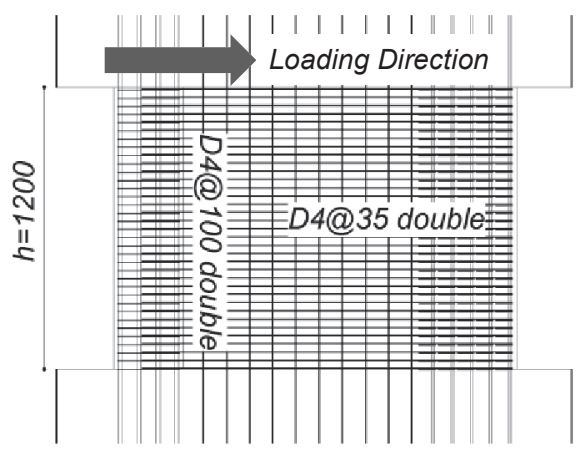

Fig.1 Elevational bar arrangements of $N(P)$ specimen (unit: $\mathrm{mm}$ )

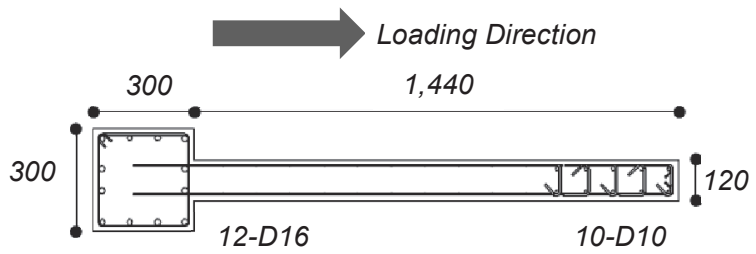

Fig.2 Plane bar arrangements of $\mathrm{N}(\mathrm{P})$ specimen (unit: $\mathrm{mm}$ )
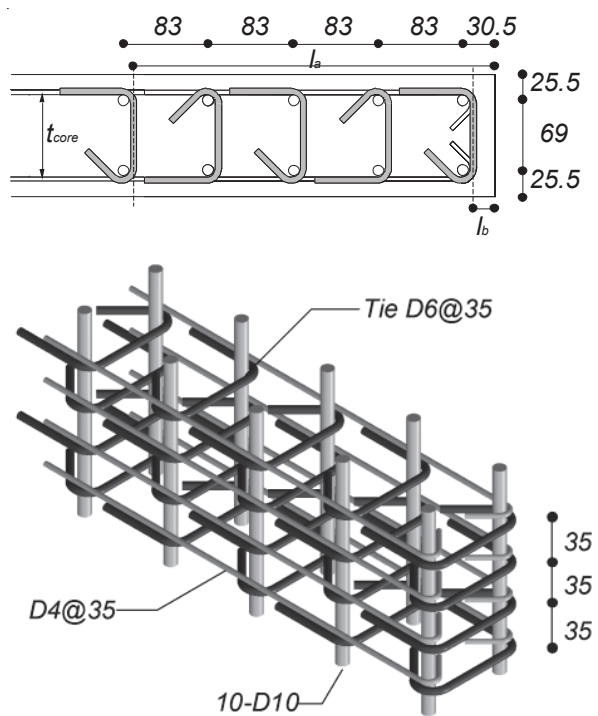

Fig.3 Close-up of confined area (unit: $\mathrm{mm}$ )

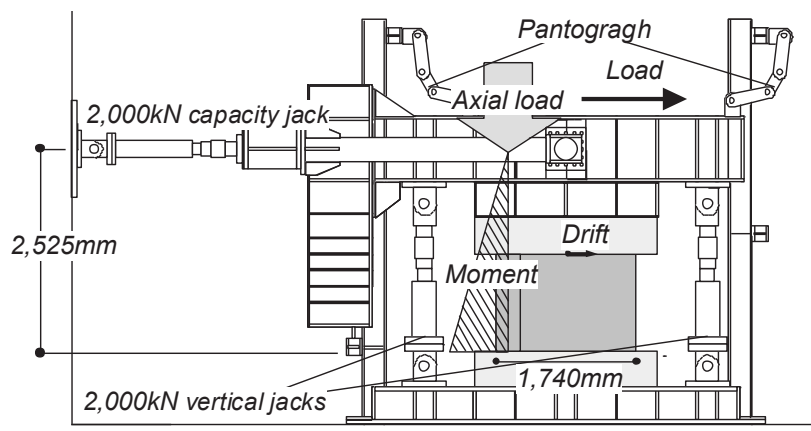

Fig.4 Test Set-up for $N(P)$
Table2 Material properties of concrete

\begin{tabular}{c|c|c}
\hline \hline Type & $\begin{array}{c}\text { Compressive strength } \\
\mathrm{N} / \mathrm{mm}^{2}\end{array}$ & $\begin{array}{c}\text { Young's modulus } \\
\times 10^{3} \mathrm{~N} / \mathrm{mm}^{2}\end{array}$ \\
\hline \hline $\mathrm{N}(\mathrm{P})$ & 36.8 & 31.3 \\
\hline $\mathrm{EN}(\mathrm{P})$ & 43.4 & 35.2 \\
\hline \hline
\end{tabular}

Table3 Material properties of reinforcing bars

\begin{tabular}{c|c|c}
\hline \hline Type & $\begin{array}{c}\text { Yield stress } \\
\mathrm{N} / \mathrm{mm}^{2}\end{array}$ & $\begin{array}{c}\text { Young's modulus }\left(E_{S}\right) \\
\times 10^{3} \mathrm{~N} / \mathrm{mm}^{2}\end{array}$ \\
\hline \hline D4 & 395.4 & 179.7 \\
\hline D6 & 425.4 & 166.2 \\
\hline D10 & 376.3 & 171.3 \\
\hline D16 & 396.5 & 166.4 \\
\hline \hline
\end{tabular}

Fig.3 は試験体の壁端部拘束域の拡大断面困および三次元困を示 している。拘束域には Table1 に示したように主筋 10-D10, 横筋 D4@35 ダブルに加え，両端に 90，135のフックを設けた D6@35 の幅止筋（3D 図中の濃灰色）を配した。

使用したコンクリートと鉄筋の材料特性をそれぞれ Table 2 およ びTable3 に示す。

\section{2 載荷計画}

Fig.4に載荷装置を示す。水平荷重は試験体危険断面より $2,525 \mathrm{~mm}$ 上方の載荷梁を通じ，付帯柱がない側が圧縮となるよう 同図の矢印方向へ一方向に漸増載荷した。軸力は 2 本の鉛直ジャッ キにより，付帯柱中心に軸力比（柱断面に対する值）が約 0.2 とな るように $540 \mathrm{kN}$ 与えた。耐力低下後の挙動も調べるため, 変位制御 により制御変形角（二壁頂部変位／壁高さ $1,200 \mathrm{~mm}$ ) $5.0 \%$ まで載荷 を行った。シアスパン比は約 $1.5(=2,525 \mathrm{~mm} / 1,740 \mathrm{~mm})$ でる。

\section{3 実験結果}

Fig.5 に $\mathrm{N}(\mathrm{P})$ 試験体の荷重変形関係を示す。試験体は曲げ降伏後 に壁端部拘束域の圧縮破壊により耐力が低下した。急激な耐力低下 開始点（同図よりおよそ線形な耐力低下剛性が得られる開始点）の 変形角は約 $2.2 \%$ あったた。以ではこの変形を曲げ圧縮破壊変形 (ここで，次元は長さ（変位）である）と呼称するが，その根拠に ついては 3.4 節の解析的分析を通して後述する。なお, 本試験体の 曲げ圧縮破壊変形は結果的に耐力が最大耐力の $90 \%$ まで低下した 変形に相当した。Fig.6に試験体の曲げ圧縮破壊直後(変形角 $2.5 \%$ ) の損傷状況を示す。壁端部コンクリートの圧壊による損傷領域の高 さは $300 \mathrm{~mm}$ 程度であった。

試験体の曲げ挙動について検討する。Fig.7 に示す変位計を用い て, Fig.8 に曲げ圧縮破壊変形時の壁圧縮側および引張側の高さ方 向の曲率分布を示す。ここで, 壁圧縮側と引張側とは, Fig.7 の N1 3 の変位計を式(1)より評価した中立軸位置に配したため, N-W 間と $\mathrm{E}-\mathrm{N}$ 間と定義した。なお，式(1)による中立軸位置が実験結果と整合 することを両者の比較を通して確認しているが，その内容は Fig.19 において後述する。また，同図の圧縮側 N-W 間では，実験計画時よ り圧縮側の損傷領域が $300 \mathrm{~mm}$ となることを文献 5)より予測し Fig.7 の計測区間 $300 \mathrm{~mm}$ の N4,W4 を配したため, これらの計測值 


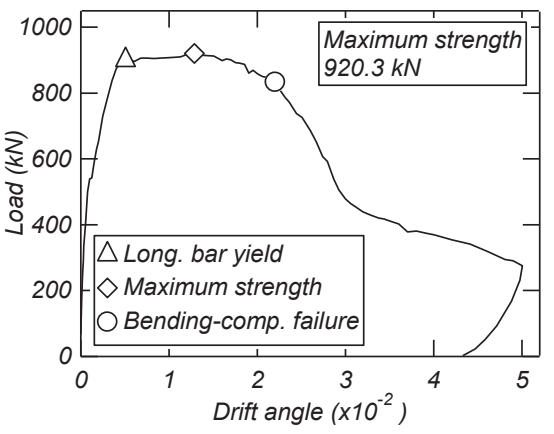

Fig.5 Load-drift angle relationship

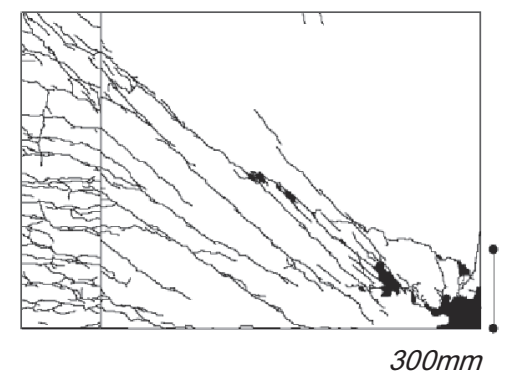

Fig.6 Crack pattern after failure $(R=2.5 \%)$

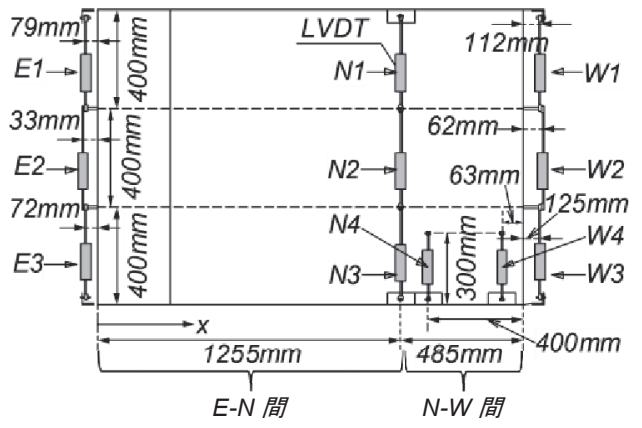

Fig.7 LVDTs arrangement

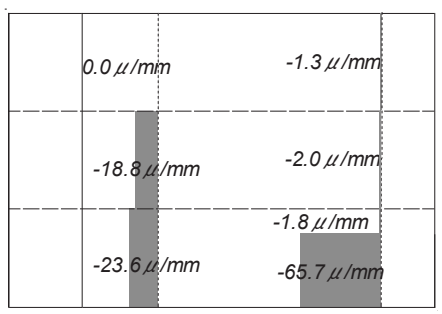

Fig.8 Curvature distributions along specimen height $(R=2.2 \%)$

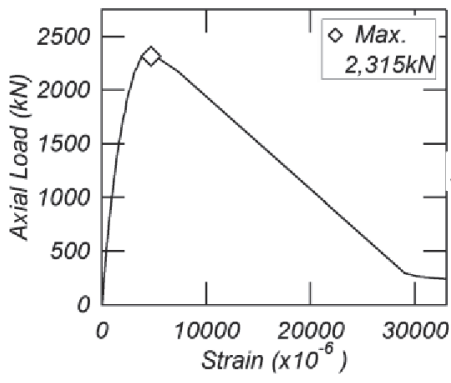

Fig.11 Axial load-strain relationship

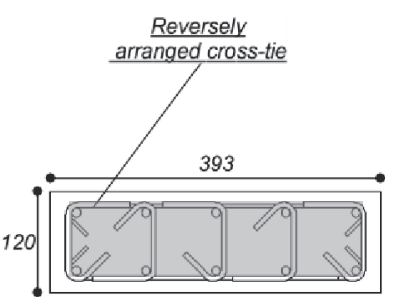

Fig.9 Details of $\mathrm{EN}(\mathrm{P})$ specimen (unit: $\mathrm{mm}$ ) 示す通りである。

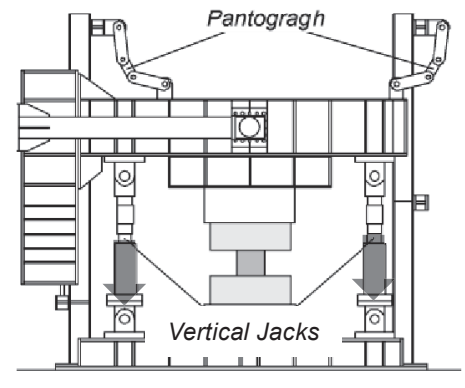

Fig.10 Test set-up for $\mathrm{EN}(\mathrm{P})$

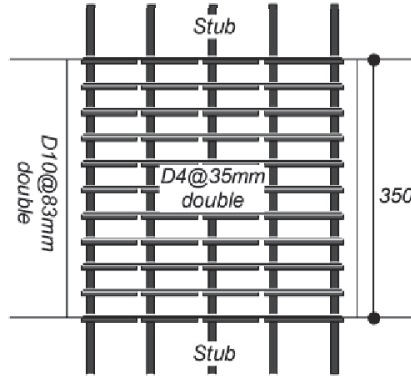

Fig.9 に N(P)試験体の壁端部拘束域のヒンジ高さを含む領域を切 り出した EN(P)試験体の配筋図を示す。Fig.3 と比較してわかるよ うに壁端部の幅止筋のみ $\mathrm{N}(\mathrm{P})$ 試験体の幅止筋を反転させて配した。 $\mathrm{N}(\mathrm{P})$ 試験体の実験においてコンクリートの圧縮破壊が壁脚部の $300 \mathrm{~mm}$ に集中したため（Figs.6, 8)，EN(P)試験体高さは試験体上 部のめり込みの可能性 7)も考慮し, 350mm とした。使用したコンク リートは Table2 の下段に，鉄筋は N(P)試験体と同様で Table3 に

載荷装置を Fig.10 に示す。装置は Fig.4 と同一であり，水平変位 は同図中の水平ジャッキ,面外変位はパンタグラフにより拘束した。 $\mathrm{EN}(\mathrm{P})$ 試験体の圧縮力下の挙動を評価するため鉛直方向押切載荷を 行った。Fig.11は実駼結果の圧縮力ー平均ひずみ関係を示している。 平均ひずみとは試験体四隅，脚部より高さ $300 \mathrm{~mm}$ の区間に配した 4 台の変位計の計測值を検長で除した值の平均值である。試験体は 平均ひずみの増加に伴い耐力上昇し， $\varepsilon=4,810 \mu$ のとき最大耐力を 迎えた。その後, 耐力低下を伴って急激に変形が進行した。急激な 耐力低下後 $(\varepsilon=29,000 \mu)$, 試験体の主筋は座屈し, 幅止筋の $90^{\circ}$ フ ックが開いていることを確認した。試験体上部のスタブへのめり込 みは観察されず，コンクリートの圧壊は前章の耐震壁と同様に試験 体下部 $300 \mathrm{~mm}$ で主に観測された（Fig.12）。

3.2 要素実験のシミュレーション解析によるコンクリートモデルの 同定

要素実験を断面解析で再現するため，試験体の危険断面を主筋， 拘束コンクリート (Fig.9 の灰色の領域で, 長さ方向と厚さ方向で, それぞれ両端幅止筋の中心間距離)，非拘束コンクリート(同図の主 筋と拘束コンクリートを除く領域）に分割した。各構成要素のモデ ル化について, 鉄筋は Fig.13 に示す材料試験の応力ひずみ関係の結 果より，降伏後の剛性を $0.001 \times E_{S}\left(E_{S}\right.$ : 鉄筋のヤング係数）とす るバイリニア型とした。なお，圧縮応力下における座屈は考慮して いない。コンクリートのモデル化には様々な方法が存在するため, 
Table4 Summary of concrete models

\begin{tabular}{|c|c|c|c|}
\hline & \multirow{3}{*}{ Stress-strain relationship } & Up to peak strength & Beyond peak strength \\
\hline & & $\begin{array}{c}\text { Compressive strength } \\
\left(\mathrm{N} / \mathrm{mm}^{2}\right)\end{array}$ & $\begin{array}{c}85 \% \text { strength beyond peak } \\
\left(\mathrm{N} / \mathrm{mm}^{2}\right)\end{array}$ \\
\hline & & Strain at peak strength $(-)$ & Strain at $85 \%$ strength $(-)$ \\
\hline \multirow{2}{*}{ Hognestad ${ }^{8)}$} & $\sigma\left(\varepsilon_{x^{\prime}}\right)=f_{c}^{\prime}\left[\frac{2 \varepsilon_{x^{\prime}}}{\varepsilon_{01}}-\left(\frac{\varepsilon_{x^{\prime}}}{\varepsilon_{01}}\right)^{2}\right]$ & $f_{c}^{\prime}=43.4 \quad($ Table 2$)$ & $0.85 \times f_{c}^{\prime}=36.9$ \\
\hline & $\sigma\left(\varepsilon_{x^{\prime}}\right)=\frac{3 f_{c}^{\prime} \varepsilon_{x^{\prime}}+f_{c}^{\prime}\left(17 \varepsilon_{01}-20 \varepsilon_{085}\right)}{20\left(\varepsilon_{01}-\varepsilon_{085}\right)} \quad \varepsilon_{01} \leq \varepsilon_{x^{\prime}}$ & $\varepsilon_{01}=0.002$ & $\varepsilon_{085}=0.0038$ \\
\hline
\end{tabular}

$f_{c}^{\prime}$ : シリンダー圧縮強度, $\varepsilon_{01}$ : 非拘束コンクリートの圧縮強度時ひずみ (一般に 0.002$), \varepsilon_{085}$ : 非拘束コンクリートの圧縮強度後の $85 \%$ 強度時ひずみ

\begin{tabular}{|c|c|c|c|c|c|c|}
\hline Modified & $\sigma\left(\varepsilon_{x^{\prime}}\right)=K^{\prime} f_{c}^{\prime}$ & $\frac{2 \varepsilon_{x^{\prime}}}{0.002 K^{\prime}}-$ & $\left(\frac{\varepsilon_{x^{\prime}}}{0.002 K^{\prime}}\right)^{2}$ & $0 \leq \varepsilon_{x^{\prime}}<0.002 K^{\prime}$ & $f_{c}^{\prime \prime}=K^{\prime} f_{c}^{\prime}=f_{c}^{\prime}\left(1+\frac{\rho_{s} f_{y h}}{f_{c}^{\prime}}\right)=48.1$ & $f^{\prime \prime}{ }_{c 85}=0.85 \times f^{\prime \prime}{ }_{c}=40.9$ \\
\hline Kent-Park 9) & $\sigma\left(\varepsilon_{x^{\prime}}\right)=K^{\prime} f_{c}^{\prime}$ & {$\left[1-Z_{m}\left(\varepsilon_{x^{x}}\right.\right.$} & $\left.\left.-0.002 K^{\prime}\right)\right]$ & $0.002 K^{\prime} \leq \varepsilon_{x^{\prime}}$ & $\varepsilon_{\text {peak }}=0.002 \cdot\left(1+\frac{\rho_{s} f_{y h}}{f_{c}^{\prime}}\right)=0.0022$ & $\varepsilon_{\text {peaks }}=0.0064$ \\
\hline
\end{tabular}

$K^{\prime}$ : 拘束効果を考慮するための係数 ${ }^{9)}, Z_{m}$ : 下降域の骨格曲線の傾きを評価する係数 ${ }^{9)}, f_{c}^{\prime \prime}$ : 拘束コンクリートの圧縮強度, $\rho_{s}$ : 横補 強筋の体積比, $f_{y h}$ : 横補強筋の降伏応力, $f^{\prime \prime}{ }^{\prime} 85$ : 拘束コンクリートの圧縮強度の $85 \%$ 強度, $\varepsilon_{p e a k}$ : 拘束コンクリートの圧縮強度時ひず み, $\varepsilon_{\text {peak } 85}$ : 応力ひずみ関係に基づく拘束コンクリートの圧縮強度後の $85 \%$ 強度時ひずみ

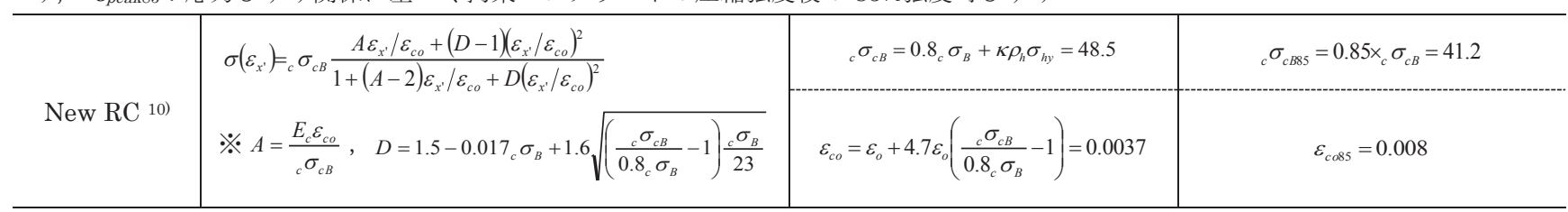

${ }_{c} \sigma_{c B}$ : 拘束コンクリートの圧縮強度, $E_{c}$ : ヤング係数, ${ }_{c} \sigma_{B}$ : シリンダーの圧縮強度, $\kappa$ : 使用骨材による係数, $\rho_{h}$ : 横補強筋の体積比, $\sigma_{h y}$ : 横補強筋の降伏応力, $\varepsilon_{c o}$ : 拘束コンクリートの圧縮強度時ひずみ, $\varepsilon_{o}$ : 非拘束コンクリートの圧縮強度時ひずみ (一般に 0.002$)$, ${ }_{c} \sigma_{c B 85}$ : 拘束コンクリートの圧縮強度の $85 \%$ 強度, $\varepsilon_{c 085}$ : 応力ひずみ関係に基づく拘束コンクリートの圧縮強度後の $85 \%$ 強度時ひずみ

\begin{tabular}{l|lc|c|c}
\hline & $\sigma\left(\varepsilon_{x^{\prime}}\right)=f_{c c}^{\prime}\left[\frac{2 \varepsilon_{x^{\prime}}}{\varepsilon_{1}}-\left(\frac{\varepsilon_{x^{\prime}}}{\varepsilon_{1}}\right)^{2}\right]^{\prime /(1+2 K)}$ & $0 \leq \varepsilon_{x^{\prime}}<\varepsilon_{1}$ & $f_{c c}^{\prime}=f_{c o}^{\prime}+k_{1} f_{l e}=55.0$ & $f_{c 855}^{\prime}=0.85 \times f_{c c}^{\prime}=46.8$ \\
Saatcioglu 11) & $\sigma\left(\varepsilon_{x^{\prime}}\right)=\frac{3 f_{c c}^{\prime} \varepsilon_{x^{\prime}}+f_{c c}^{\prime}\left(17 \varepsilon_{1}-20 \varepsilon_{85}\right)}{20\left(\varepsilon_{1}-\varepsilon_{85}\right)}$ & $\varepsilon_{1} \leq \varepsilon_{x^{\prime}}$ & $\varepsilon_{1}=\varepsilon_{01}(1+5 K)=0.0069$ & $\varepsilon_{85}=260 \rho \varepsilon_{1}+\varepsilon_{085}=0.027$ \\
\hline
\end{tabular}

$f_{c c}^{\prime}$ : 拘束コンクリートの圧縮強度, $K$ : 拘束効果を考慮するための係数 $\left.{ }^{11}\right)(\mathrm{EN}(\mathrm{P})$ 試験体では 0.49$), f_{c o}^{\prime}:$ プレーンコンクリートの圧 縮強度, $k_{1}$ : 横拘束圧力の補正係数 ${ }^{11}, f_{l e}$ : 横拘束を一様として考えたときの圧力 ${ }^{11}, \varepsilon_{1}$ : 拘束コンクリートの圧縮強度時ひずみ, $f_{c 855}^{\prime}$ : 拘束コンクリートの圧縮強度の $85 \%$ 強度, $\varepsilon_{85}$ : 拘束コンクリートの圧縮強度後の $85 \%$ 強度時ひずみ

本解析では Hognestad モデル 8), 修正 Kent-Park モデル 9), New $\mathrm{RC}$ モデル 10), Saatcioglu モデル 11)の 4 モデルを採用して比較検討 を行った。各モデルによる骨格曲線の概要と特異点を Table4 にま とめる。ただし，横補強筋の拘束効果を考慮できない Hognestad モ デルを除き，同表では拘束コンクリートの圧縮特性について掲載し た。また, 材料試験結果との比較を Fig.14に示す。ただし, 同図で は Hognestad モデルを除くモデルでは $\mathrm{EN}(\mathrm{P})$ 試験体の拘束コンク リートの骨格曲線である。Hognestad モデルは, 横補強筋の拘束を 考慮していないため, 材料試験結果とは最も対応している。そこで, 非拘束コンクリートは Hognestad モデルを用いて表現することと した。

上記の (Hognestad を除く) 拘束コンクリートのモデルを解析パ ラメータとして要素実験のシミュレーション（押切載荷解析）を行 い, 要素実験結果を高精度に再現する拘束コンクリートのモデルを 同定する。各モデルを用いた軸方向の断面解析より得られた圧縮力
(拘束コンクリートの断面積 $\times$ 応力度 + 非拘束コンクリートの断面 積 $\times$ 応力度 + 鉄筋の断面積 $\times$ 応力度）－平均ひずみ関係を実験結果 と Fig.15 で比較する。図より, 実験結果の再現性は Saatcioglu モ デルが高く, とくに圧縮強度時ひずみの解析值 $5,100 \mu$ が実験值 $4,810 \mu$ とよい整合を示した。一方, 修正 Kent-Park モデルと NewRC モデルでは圧縮強度時ひずみがそれぞれ $2,200 \mu, 3,000 \mu$ であり過 小評価されたことがわかる。これは Fig.14 で示したように， Saatcioglu モデルでは拘束効果による圧縮強度時ひずみの増大が他 の 2 モデルに比べて大きく評価された結果に起因寸る。以上より, 以降の耐震壁実験の解析では, 非拘束コンクリートに Hognestad モ デル，拘束コンクリートに Saatcioglu モデルを採用する。一方で, Fig.15の Saatcioglu モデルによる評価結果は初期剛性および圧縮 強度を超えた後の劣化剛性を高く評価していた。そこで，初期剛性 については応力上昇域の骨格曲線に拘束効果を考慮する係数 $K^{11)}$ 影響と判断し, 同曲線の定義式の指数 (Table4 参照) に対し $K=0$ と 

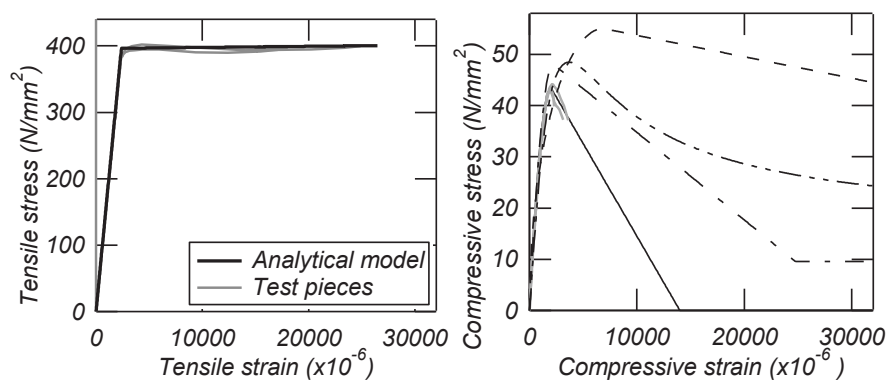

\begin{tabular}{|c|c|c|c|c|}
\hline-- & $\begin{array}{l}\text { Experimental results } \\
\text { Modified Kent-Park }\end{array}$ & $-\cdots$ & $\begin{array}{l}\text { Hognestad } \\
\text { New RC }\end{array}$ & - - - - Saatcioglu \\
\hline
\end{tabular}

Fig.13 Rebar modeling (D10)

Fig.14 Concrete modeling

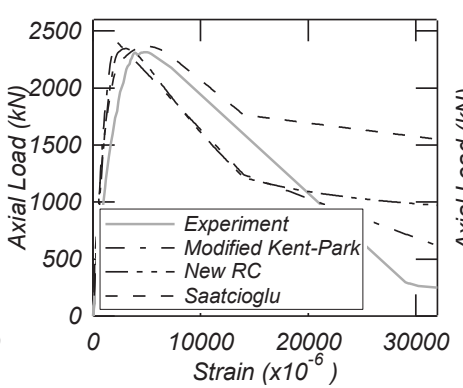

Fig.15 Comparison between analytical and test results

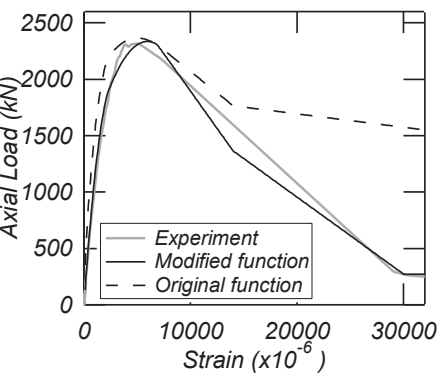

Fig.16 Comparison between modified and original curves
仮定した。また, 劣化勾配を決定する $\varepsilon_{85}$ (圧 縮強度後の $85 \%$ 強度時ひずみ) の評価式

(Table4 参照) では係数 260 が用いられて いるが, 試験体の幅止筋は片側が $90^{\circ}$ フック であり拘束効果が低下した可能性が考えら れたため, $\mathrm{EN}(\mathrm{P})$ 試験体の実験結果に基づ いて係数 75 を同定した。Fig.16 は上記の 修正前後の Saatcioglu モデルを用いた解析 結果を実験結果と比較している。修正によ り実験結果との整合性が改善されており, 以降の解析では拘束コンクリートに修正後 の Saatcioglu モデルを適用する。

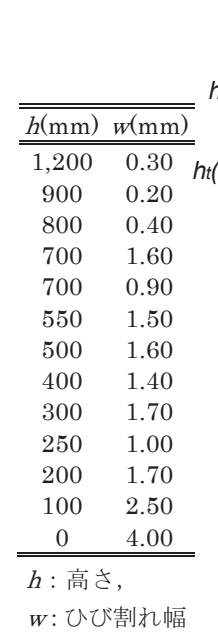

\section{3 耐震壁の不均一な塑性ヒンジを考慮す}

\section{る曲げ解析法}

文献 12)では曲げ圧縮破壊する耐震壁の圧縮側のヒンジ高さが壁 厚 $t$ の 2.5 倍程度と結論付けられている。2 章の実験結果も Figs.6, 8 に示した通り, コンクリートの圧壊領域が脚部より $300 \mathrm{~mm}(=2.5 t)$ に集中しており, 同文献の結論を支持するものである。一方, 同図 より, 引張側の損傷領域は圧縮側よりも高い壁高さまで広がった。

Fig.17 は曲げ圧縮破壊変形を迎える直前（R=2.0\%）の試験体のひ び割れ状況を示している。同図左側には付帯柱の引張縁で測定した 曲げひび割れ幅 $W$ を示すが, このとき, 曲げひび割れ幅の合計

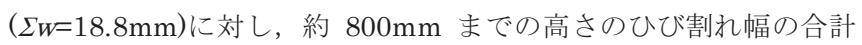
$(\Sigma W 0-800=18.3 \mathrm{~mm})$ が約 $97 \%$ を占めていた。さらに, 文献 13$)$ では, 引張ヒンジ高さは壁長さの $0.3 \sim 0.8$ 倍と指摘されていることも考 慮し, 本研究では引張縁のヒンジ高さを壁長さの半分 $(=870 \mathrm{~mm})$ と仮定した。また, Fig.17 上図より壁の圧縮域の中立軸側端部と引 張縁間のヒンジ高さは線形補間して定義すると, 引張縁から距離 $x$ におけるヒンジ高さ $h(x)$ は式(3)により表現できる。

$$
\begin{aligned}
& \cdot 0 \leq x \leq x_{n}{ }^{\prime}\left(x_{n}{ }^{\prime}=1740-x_{n}\right) \\
& h(x)=\frac{h\left(x_{n}\right)-h(0)}{x_{n}{ }^{\prime}} x+h(0)=-\frac{570}{x_{n}{ }^{\prime}} x+870=h_{t}(x) \\
& \text { • } x_{n}{ }^{\prime} \leq x \leq 1740
\end{aligned}
$$$$
h(x)=300=h_{c}
$$

ここで, $h_{c}, h_{t}$ :それぞれ圧縮, 引張側断面上のヒンジ高さである。 また, 塑性ヒンジ回転角 $\theta$ は $x$ に関わらず一定で, ヒンジ領域の曲 率 $\phi(x)$ が高さ方向に一様であると仮定すると, 塑性ヒンジ回転角 $\theta$ は 次の式(4)で表される。

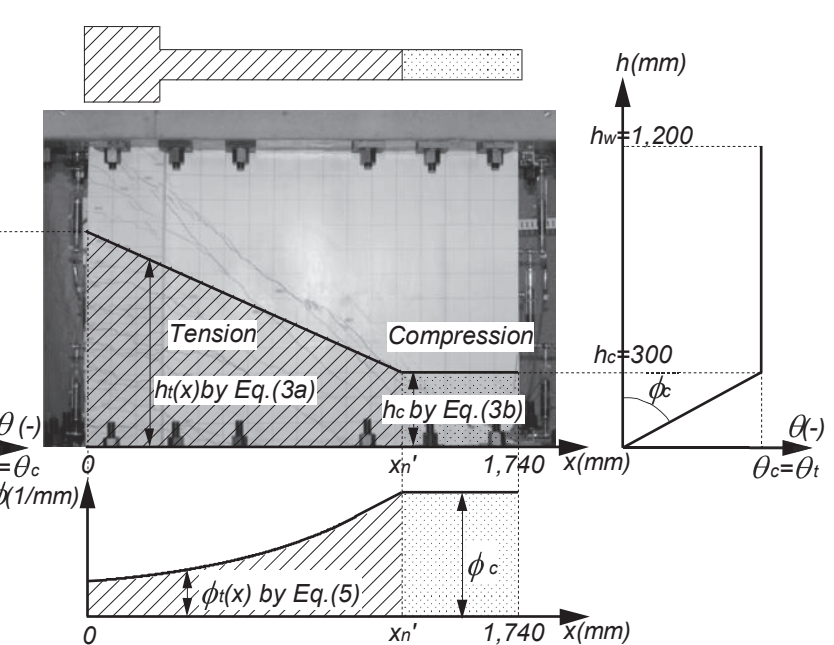

Fig. 17 Crack pattern at $\mathrm{R}=2.0 \%$ (upper) and curvature distribution along $x$ (lower)

$\theta=\phi(x) \times h(x)=\phi_{c} \cdot h_{c}=\phi_{t}(x) \cdot h_{t}(x)$

従って, 引張縁からの距離 $x$ における引張側断面の曲率 $\phi_{t}(x)$ と、 圧縮側断面の曲率 $\phi_{c}$ の関係は, 式(3a)および(3b)を式(4)に代入する ことで式(5)の通り表現される（Fig.17下図）。

$$
\phi_{t}(x)=\frac{\phi_{c} \cdot h_{c}}{h_{t}(x)}=\frac{300}{-570 / x_{n}{ }^{\prime} \cdot x+870} \cdot \phi_{c} \quad\left(0 \leq x \leq x_{n}{ }^{\prime}\right)
$$

式(5)より求めた危険断面の曲率分布を適用して, 圧縮側の曲率を 漸増する曲げ解析を行った。Fig.18に上記の方法に基づく曲げ解析 より得られたモーメントー平均曲率関係を実駼結果と比較する。こ こで, 平均曲率とは解析では壁圧縮縁と引張縁のひずみに基づく平 均的な曲率（両ひずみの差分を壁長さで除した值）を意味し，実験 では Fig.7 の E3 と W4 の変位計の測定值に基づく曲率である。図 中の黒線が解析結果でそのうち点線が一般的な平面保持仮定を用い た場合の結果である。Fig.18より本研究で提案した解析方法は実験 結果の再現性が総じて高く, 骨格曲線を概子精度よく評価できてい る。一方, 従来の平面保持仮定に基づく解析ではとくに変形性能を 大幅に過大評価していることがわかる。式(5)に示すように提案手法 では圧縮域の曲率が引張域よりも大きいため, 相対的に小さな平均 曲率におけるコンクリートの圧壊を模擬できることを意味している。 また, Fig.19 は中立軸位置と平均曲率の関係について提案手法によ る解析結果と実験結果を比較している。中立軸位置の実験結果は,

Fig.7 に示す脚部に配した変位計からひずみが 0 となる点を, 付帯 柱引張縁からの距離として示している。同図より, 解析結果は実験 結果と概初整合し，ともに試験体危険断面の中立軸位置は曲げ降伏 


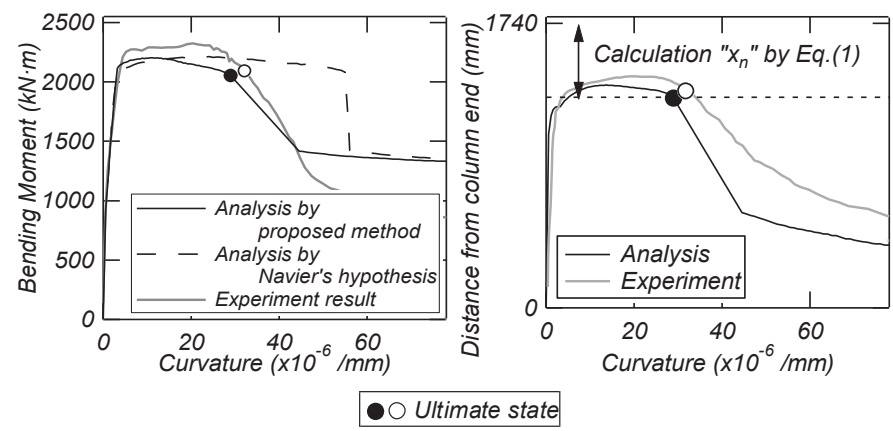

Fig.18 Moment-averaged curvature relationship
Fig.19 Neutral axis depth-averaged curvature relationship

までモーメントの増加と共に圧縮縁側へ移動し, 曲げ降伏後から耐 力低下に至るまで式(1)による算定值をほぼ限界として一定で推移 した。そして, 耐力低下とともに中立軸が引張縁側へと移動した。 従って, $\mathrm{N}(\mathrm{P})$ 試験体の急激な耐力低下開始点（Figs.18,19 の丸印の 時）の中立軸位置は式(1)により概算できる。

\section{4 中立軸を固定した断面解析に基づく曲げ圧縮破壊機構の力学的}

\section{解釈}

付帯柱のない耐震壁の曲げ圧縮破壊機構を断面の軸力と軸耐力に 着目して分析するため ${ }^{14)}, \mathrm{N}(\mathrm{P})$ 試験体について急激な耐力低下開始 点 (Fig.18の丸印の時) における中立軸位置を固定した状態で，前 節と同様の解析モデルを用いた曲げ解析を行った。Fig.20 は横軸を 平均曲率, 縦軸を圧縮域のコンクリートに作用する圧縮力と定義し た場合の両者の関係を示す。曲率 $12.5 \times 10^{-6}(1 / \mathrm{mm})$ までは断面の 圧縮力が増大し (耐力上昇域・黒色点線), その後下降 (耐力下降域・ 黒色実線）に転じることがわかる。すなわち，上記曲率時の圧縮力 は当該中立軸下において圧縮域が負担できるコンクリートの最大圧 縮耐力を意味しており, Fig.20の曲線の耐力下降域は当該曲率にお けるコンクリートの圧縮耐力（耐力曲線）と解釈できる。本試験体 の場合, この耐力曲線と作用軸力（後述の $C_{d}$ ) が曲率 $28.8 \times 10^{-6}$ (1/mm) で交差し, Fig.18 の解析結果の急激な耐力低下開始点（お よそ線形な耐力低下剛性が得られる開始点）の曲率と一致すること がわかる。すなわち, 試験体の曲げ変形に伴い圧縮域に作用する外 力が，圧縮域コンクリートで負担可能な耐力を上回るときの変形が 曲げ圧縮破壊変形に相当する。この関係と, 前述の急激な耐力低下 開始点の中立軸深さが式(1)で評価可能なことを総合すれば, 付帯柱 のない耐震壁の曲げ圧縮破壊変形を合理的に評価できる。そこで, 以下ではその評価法を誘導し, 実験結果との比較を通して検証する。

\section{4. 曲げ圧縮破壊変形の理論的評価}

\section{1 評価法の誘導}

以上の知見に基づき，付帯柱のない耐震壁の曲げ圧縮破壊変形の 理論值を圧縮域のコンクリートに対する作用軸力 $\left(C_{d}\right)$, 並びに, コ ンクリートの軸耐力を曲げ圧縮破壊点における圧縮域の曲率(以下, 限界曲率と呼称する $)$ の関数 $\left(C_{c}\left(\phi_{u}\right)\right)$ として評価することで算定す る方法を示す。なお，限界曲率 $\phi_{u}$ が得られると式(4)より耐震壁の当 該曲率時の部材角（すなわち限界曲げ変形）が得られるが，本稿で は $\phi_{u}$ の評価法と検証結果を示す。

前者の $C_{d}$ は式(1)を変形して式(6)の通り概算できる (Fig.21参考)。

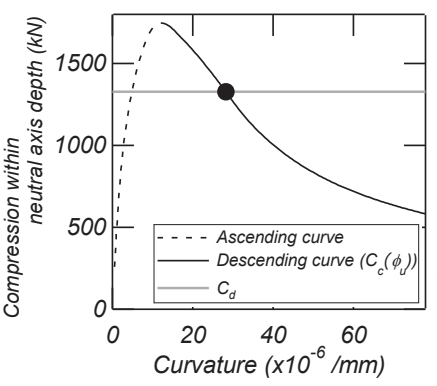

Fig.20 Compression within the neutral axis depth-averaged curvature relationship

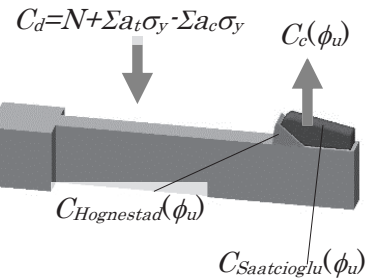
the cross section
Fig.21 $C_{d}$ and $C_{c}$ on

$$
x_{n}=\frac{N+\sum a_{t} \sigma_{y}-\sum a_{c} \sigma_{y}}{0.85 \beta \cdot f_{c}^{\prime} \cdot t} \Leftrightarrow C_{d}=0.85 \beta f^{\prime}{ }_{c} x_{n} t=N+\sum a_{t} \sigma_{y}-\sum a_{c} \sigma_{y}
$$

一方, 後者の $C_{c}\left(\phi_{u}\right)$ は, 前章で拘束コンクリートと非拘束コンク リートの材料特性をそれぞれ Saatcioglu モデル（ただし，前章と同 様に修正したモデル) と Hognestad モデルで評価できた結果に基づ き, 両モデルが限界曲率 $\phi_{u}$ 時に負担するコンクリートの圧縮力 $\left(C_{\text {Hognestad }}\left(\phi_{u}\right), C_{\text {Saatcioglu }}\left(\phi_{u}\right)\right)$ の和として表現できる。Fig.21 に示 すように，拘束域および非拘束域のコンクリートが負担する圧縮力 （圧縮軸耐力）は，コンクリートモデルの応力ひずみ曲線 $\sigma\left(\varepsilon_{x}\right)$ を用 いて，応力を断面積で積分することで式(7)により評価できる。

$C_{c}\left(\phi_{u}\right)=C_{\text {Hognestad }}\left(\phi_{u}\right)+C_{\text {Saatciogl } u}\left(\phi_{u}\right)$

$=\sum\left\{\iint\left(\varepsilon_{x^{\prime}}\right) d x d t\right\}=\sum\left\{T \int \sigma\left(\varepsilon_{x^{\prime}}\right) \frac{d \varepsilon}{\phi_{u}}\right\}=\sum\left\{\frac{T}{\phi_{u}} \int \sigma\left(\varepsilon_{x^{\prime}}\right) d \varepsilon\right\}$

Table4より

$$
\begin{aligned}
& =\sum\left\{\frac{T}{\phi_{u}}\left\langle\frac{f_{c}}{3 \varepsilon_{p}{ }^{2}}\left\{\left(3 \varepsilon_{p} \varepsilon_{B}{ }^{2}-\varepsilon_{B}{ }^{3}\right)-\left(3 \varepsilon_{p} \varepsilon_{A}{ }^{2}-\varepsilon_{A}{ }^{3}\right)\right)\right\}\right\} \\
& \text { 忘力上昇域 } \\
& +\sum\left\{\frac{T}{\phi_{u}}\left\langle\frac{f_{c}}{40\left(\varepsilon_{p}-\varepsilon_{q}\right)}\left[\left\{\left(3 \varepsilon_{D}^{2}+\left(34 \varepsilon_{p}-40 \varepsilon_{q}\right) \varepsilon_{D}\right\}-\left\{3 \varepsilon_{C}{ }^{2}+\left(34 \varepsilon_{p}-40 \varepsilon_{q}\right) \varepsilon_{C}\right\}\right]\right\}\right\}\right.
\end{aligned}
$$

\section{応力下降域}

ここで, $\sigma\left(\varepsilon_{x_{x}}\right):$ Hognestad モデル $\left({ }_{H .} \sigma\left(\varepsilon_{X^{\prime}}\right)\right)$ または Saatcioglu モ デル $\left(s . \sigma\left(\varepsilon_{x}\right)\right)$ の応力ひずみ曲線 (Table4)， $T$ ：カバーコンクリー トでは $t-t_{\text {core }}$, コアコンクリートでは $t_{\text {core }}$ ( : 拘束域厚さ, Fig. 3$)$, $f_{c}$ : 非拘束域では $f_{c}^{\prime}$ ，拘束域では $f_{c c}^{\prime}($ Table 4$), \varepsilon_{p}$ : 非拘束域では $\varepsilon_{01}$ ，拘束域では $\varepsilon_{1}(T a b l e 4), \varepsilon_{q}$ : 非拘束域では $\varepsilon_{085}$, 拘束域では $\varepsilon_{85}$ (Table4), $\varepsilon_{A}, \varepsilon_{B}, \varepsilon_{C}, \varepsilon_{D}$ は順に各コンクリートモデルの応力上昇 域のひずみ度の下限值と上限值, 応力下降域のひずみ度の下限值と 上限值である。

付帯柱のない耐震壁の限界曲率 $\phi_{u}$ 時における圧縮域の応力状態に ついて, 中立軸深さ $x_{n}$ の条件による変化の概念図を Fig. 22 に示寸。 同図中， 1 段目は圧縮域の断面図，2 段目は圧縮域の曲率により発 生するひずみ分布図，3 5 段目はそれぞれカバー（非拘束コンクリ 一ト)，拘束域以外 (壁板) のコア (非拘束コンクリート)，拘束域 のコア（拘束コンクリート）の応力状態である。また, 同図(a)から (d)に向かうほど，圧縮域が拡大寸る（中立軸深さが大きい）状態を 示している。圧縮域のコンクリートに対する作用軸力 $\left(C_{d}\right)$ と圧縮 軸耐力の釣合 $\left(C_{d}=C_{c}\left(\phi_{u}\right)\right)$ を条件として $\phi_{u}$ について数式を解くと, 

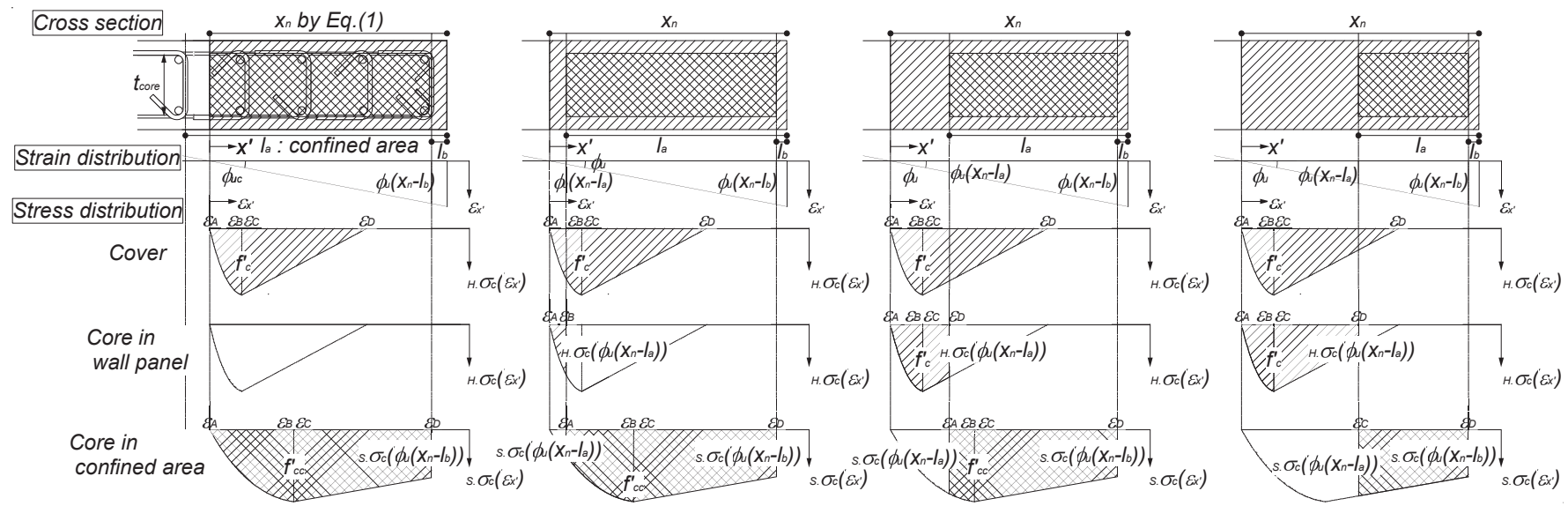

Note: 1) each $\varepsilon$ means integral lower and upper limit;

2) the post peak stress of unconfined / confined concrete lost / sustained the resistance at the wall edge for all specimens in this paper

(a) Stress condition (CaseA)

(b) Stress condition (CaseB1)

(c) Stress condition (CaseB2)

(d) Stress condition (CaseB3)

Fig.22 Stress conditions depending on $x_{n}$

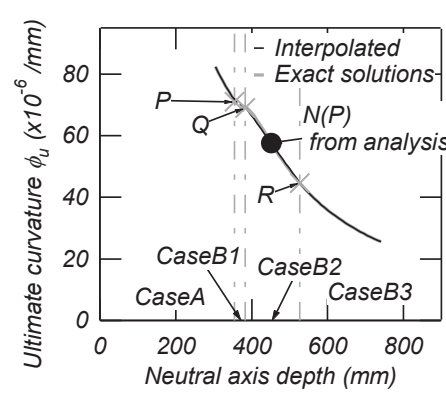

Fig.23 Ultimate curvature neutral axis depth relationship

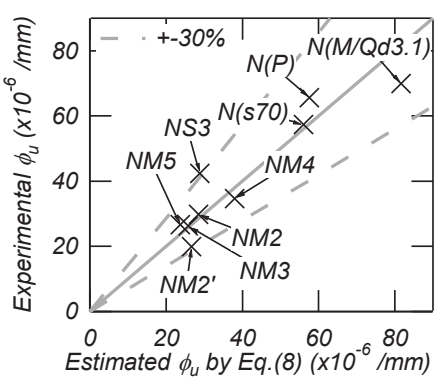

Fig.24 Comparison of ultimate curvature between experiment and Eq.(8)

付帯柱のない耐震壁の圧縮域の限界曲率が求まる。ただし, この算 定では, 中立軸深さ $x_{n}$ と結果として求まる $\phi_{u}$ に応じて, 釣合式の解 が Fig.22(a)から (d) に対応する以下の 4 通りの条件に応じて異なる。 CaseA：中立軸が壁端部拘束域内にある場合 $\left(x_{n} \leqq l_{a}\right.$, Fig.22(a) CaseB : 中立軸が壁端部拘束域より付帯柱側にある場合 $\left(x_{n}>l_{a}\right)$ (CaseB1) 拘束域の中立軸側端部のひずみ度 $\varepsilon_{A}$ が同位置の非拘束コ ンクリートの圧縮強度時ひずみ度 $\varepsilon_{01}$ 以下（応力上昇域のひずみ度） の場合 $\left(l_{a}<x_{n} \leqq l_{a}+\varepsilon_{01} / \phi_{u}\right.$, Fig.22(b))

(CaseB2) 拘束域の中立軸側端部のひずみ度 $\varepsilon_{A}$ が同位置の非拘束コ ンクリートの圧縮強度時ひずみ度 $\varepsilon_{01}$ を超過し（応力下降域のひずみ 度), 拘束域コンクリートの圧縮強度時ひずみ度 $\varepsilon_{1}$ 以下 (応力上昇域 のひずみ度）の場合 $\left(l_{a}+\varepsilon_{01} / \phi_{u}<X_{n} \leqq l_{a}+\varepsilon_{1} / \phi_{u}\right.$, Fig.22(c)

(CaseB3) 拘束域の中立軸側端部のひずみ度が拘束域コンクリート の圧縮強度時ひずみ度 $\varepsilon_{1}$ を超過する（応力下降域のひずみ度）場合 $\left(x_{n}>l_{a}+\varepsilon_{1} / \phi_{u}\right.$, Fig.22(d))

以上，4つの場合分けに際して，中立軸深さは式(1)より既知であ るため, 評価対象とする耐震壁が CaseA あるいは CaseB のいずれ に該当するかは予め判定が可能である。また, CaseB1 および CaseB2 に該当する場合, $\phi_{u}$ の評価式が 3 次方程式となり実用的で ないため, この間は各領域の境界 (境界 $\mathrm{P}$ : CaseA と CaseB1 の境 界, Q : CaseB1 と CaseB2 の境界, R：CaseB2 と CaseB3 の境界

と定義する）における $\phi_{u}$ を線形補間することで計算の簡略化を図る こととした。CaseA, CaseB3 に該当する場合および点 P, Q , R に おける $C_{d}=C_{c}\left(\phi_{u}\right)$ の条件下では $\phi_{u}$ の評価式が 2 次方程式であり, そ の解 $\phi_{u}$ の算定式を付録にまとめる。

\section{2 評価法の適用と検証}

上記の評価方法に基づいて $\mathrm{N}(\mathrm{P})$ 試験体について $x_{n}$ を変数とした 場合の $\phi_{u}$ の推移を Fig.23 に黒色実線で示す。なお， $x_{n}$ の漸増（式 （1）より作用軸力の漸増を意味する）とともに変形性能が漸減するこ とがわかる。また, 同図には CaseB1 と CaseB2 の場合の精密解 (式 (7)の $\varepsilon_{A}, \varepsilon_{B}, \varepsilon_{C}, \varepsilon_{D}$ に Fig.22(b),(c)の条件を代入して得られる $\phi_{u}$ に 関する 3 次方程式の解）を灰色実線で示すが，近似解（Fig.23の点 $\mathrm{P}, \mathrm{Q}, \mathrm{R}$ において 2 次方程式の解として得られる $\phi_{u}$ に基づく線形補 間值）との差は最大で $2 \%$ あり，上記の近似方法で評価可能であ ることがわかる。

本論文で示した $\mathrm{N}(\mathrm{P})$ 試験体および文献 3)の繰り返し載荷された 試験体（ただし，脚部で大きなせん断すべりが観察された旨の報告 されている NL2 試験体 15), N 試験体 5)を除く) 合計 9 体について, 以上の方法により算定した限界曲率 $\left(\phi_{u}\right)$ と実験結果の限界曲率 (急 激な耐力低下開始点すなわち曲げ圧縮破壞変形における圧縮域曲率 であり, Fig.7 のN4 と W4 の変位計の測定值に基づく曲率)を Fig.24 で比較する。なお, 文献 3)の試験体の限界曲率は, 本稿において耐 力劣化や中立軸位置に関する実験結果を含めて総合的に再検討した ところ, 結果的に耐力が最大耐力の $85 \%$ に低下した変形に相当した ことを補足する。計算值は総じて実験結果を精度よく評価できた。 以上により, 付帯柱のない耐震壁の限界曲率は式(6) と式(7)の釣り合 い（作用軸力と軸耐力の釣り合い）に基づいて評価できる。本研究 で扱った試験体の範囲では, 鉄筋の座屈を考慮しない解析仮定の下 で Fig.24の限界曲率の評価精度が得られた。ただし, 一定の条件下 では鉄筋の座屈が耐震壁の圧縮域の性能に影響する実験結果も報告 されているため 16 , 鉄筋の座屈が有意に影響する条件については今 後の研究を待つ必要がある。 


\section{5. まとめ}

付帯柱がない RC 而震壁の曲げ変形性能を評価するため, 付帯柱 がない壁端部が圧縮される押切載荷実験結果に基づいて, 高精度な 曲げ解析法と限界曲率の略算法を提案, 検証した。以下に本研究よ り得られた知見をまとめる。

1）実験結果より, 試験体は付帯柱のない壁端部コンクリートの曲 げ圧壊により耐力が低下した。コンクリートの破壊領域の高さ (ヒンジ高さ) は壁厚のおよそ 2.5 倍であった。一方, 引張側の 損傷領域（ヒンジ高さ）は圧縮側より大きかった。

2）上記の知見を踏まえて, 圧縮側ヒンジ高さを壁厚の 2.5 倍, 引 張側ヒンジ高さを壁長さの $1 / 2$ 倍と仮定し, 壁脚部の不均一な 曲率分布を考慮する曲げ解析法を提案し, 実験結果を従来の平 面保持仮定に基づく解析より精度よく再現可能であることを検 証した。

3）上記の曲げ解析法を援用し，耐震壁の曲げ圧縮破壊変形（限界 曲率）の支配要因が圧縮域の作用軸力と軸耐力（すなわち, 軸力 比）であることを示した。

4）耐震壁の圧縮域の作用軸力と軸耐力の釣り合いに基づいて，曲 げ圧縮破壊変形 (限界曲率) の略算法を導き, 上記試験体と先行 研究で実験された試験体の急激な耐力低下時の曲率とよく整合 することを示した。

\section{謝辞}

本研究は国土交通省の平成 24 年度建築基準整備促進事業の一環 として実施した。本稿で報告した実験は名古屋工業大学 市之瀬敏勝 教授, 高橋之助教, 建築研究所 福山洋博士, 谷昌典博士と共同で実 施したものである。ここに記して謝意を表す。

\section{参考文献}

1）日本建築学会：鉄筋コンクリート構造計算規準・同解説， 2010.2

2) Wallace J.W., Massone L.M., Bonelli P., Dragovich J., Lagos R., Luders C. and Moehle J.: Damage and Implications for Seismic Design of RC Structural Wall Buildings, Earthquake Spectra, 28 (S1): S281-S299, 2012.6

3）松原聡平, 真田靖士, 谷昌典, 高橋之, 市之瀬敏勝, 福山洋 : 曲げ圧縮破 壊する耐震壁の曲げ変形性能に対する拘束域の影響因子, 日本建築学会 構造系論文集，Vol.78，No.691，pp1593-1602，2013.9

4) 山本直樹, 真田靖士, 松原聡平, 尹ロク現, 谷昌典, 高橋之, 市之瀬敏勝, 福山洋: 曲げ破壞型耐力壁の押切載荷実験と曲げ解析, 日本建築学会近畿 支部研究報告集，構造系 Vol.53，pp.317-320，2013.5

5）松原聡平, 真田靖士, 高橋之, 市之瀬敏勝: 曲げ破壊型而力壁の変形性能 に圧縮端拘束域の構造詳細が与える影響に関する実験的研究，コンクリ 一ト工学年次論文集, Vol.34, No.2, pp.361-366, 2012.7

6) American Concrete Institute(ACI): Building Code Requirements for Structural Concrete and Commentary (ACI 318M-11), 2011.6

7）今井和正, 是永健好, 瀧口克己：めり込みを考慮した $\mathrm{RC}$ 部材端部の回転 変形解析法, 日本建築学会構造系論文集, No.562, pp.99-105, 2002.12

8) Hognestad E., Hanson N.W. and McHenry D.: Concrete Stress Distribution in Ultimate Strength Design, ACI Journal, 52(12): 455480, 1955.12

9) Scott B.D., Park R. and Priestley M.J.N.: Stress-Strain Behavior of Concrete Confined by Overlapping Hoops at Low and High Stain Rates, ACI Journal, 79(2): 13-27, 1982.1

10）日本建築学会 : 鉄筋コンクリート造建物の耐震性能評価指針（案）・同解 説, 2004.1
11) Saatcioglu M. and Razvi S.: Strength and Ductility of Confined Concrete, ASCE Journal of Structural Engineering, 118(6): 1590-1607, 1992.6

12）高橋之, 吉田和也, 市之瀬敏勝, 真田靖士, 松本健規, 福山洋, 諏訪田晴 彦: 圧縮側に柱型がない $\mathrm{RC}$ 耐震壁の曲げ変形性能, 日本建築学会構造系 論文集, Vol.76, No.660, pp.371-377, 2011.2

13) Paulay T. and Priestley M.J.N.: Seismic Design of Reinforced Concrete and Masonry Buildings, John Wiley \& Sons Inc. New York, 1992.3

14）鈴木計夫, 中塚佶, 阿波野昌幸：コンクリートはり部材断面の曲げ終局限 界点に関する研究，その 1 各種終局域指標点と提案する曲げ終局限界点 の存在メカニズム, 日本建築学会構造系論文報告集, No.383, pp.49-57, 1988.1

15）泉徳秀, 高橋之, 松原聡平, 真田靖士, 松本健規, 遠山誉, 吉田和也,福山 洋, 諏訪田晴彦, 市之瀬敏勝 : 曲げ降伏型片側柱付き $\mathrm{RC}$ 耐震壁の復元力 特性, 日本建築学会東海支部研究報告集, Vol.49, pp.281-292, 2011.2

16) Rafik Taleb, Masaya Ogura, Susumu Kono, and Masanori Tani: Performance of Confined Boundary Regions of RC Rectangular Walls under Cyclic Reversal Loadings，コンクリート工学年次論文集, Vol.36, No.2, pp.325-330, 2014.7 
付録 限界曲率の算定式

限界曲率算定のために導いた式(8)を付録に示す。いずれの式も 式(7)にそれぞれの積分区間のひずみ度を代入し, 式変形すること で得ることができる。それぞれの積分区間の場合分けは Table5 に 示す通りである。

Table5 Values for parameters in functions

\begin{tabular}{|c|c|c|c|c|c|c|c|c|c|}
\hline & & Area in Fig.22 & model & width $\mathrm{T}$ & $\varepsilon_{\mathrm{A}}$ & $\varepsilon_{\mathrm{B}}$ & $\varepsilon_{\mathrm{C}}$ & $\varepsilon \mathrm{D}$ & Solution \\
\hline & \multirow{3}{*}{$\begin{array}{l}\text { CaseA } \\
\left(x_{n}<l_{a}\right)\end{array}$} & Cover & \multirow{2}{*}{ Hognestad } & $t-t_{\text {core }}$ & 0 & $\varepsilon_{01}$ & $\varepsilon_{01}$ & $\varepsilon_{00}$ & \multirow{3}{*}{ (8.A) } \\
\hline & & Core in wall panel & & $t_{\text {core }}$ & & & & & \\
\hline & & Core in confined area & Saatcioglu & $t_{\text {core }}$ & 0 & $\varepsilon_{1}$ & $\varepsilon_{1}$ & $\phi_{u}\left(x_{n}-I_{b}\right)$ & \\
\hline & \multirow{3}{*}{$\begin{array}{l}\text { PointP } \\
\left(x_{n}=l_{a}\right)\end{array}$} & Cover & \multirow{2}{*}{ Hognestad } & $t-t_{\text {core }}$ & 0 & $\varepsilon_{01}$ & $\varepsilon_{01}$ & $\varepsilon_{00}$ & \multirow{3}{*}{ (8.P) } \\
\hline & & Core in wall panel & & $t_{\text {core }}$ & & & & & \\
\hline & & Core in confined area & Saatcioglu & $t_{\text {core }}$ & 0 & $\varepsilon_{1}$ & $\varepsilon_{1}$ & $\phi_{u}\left(l_{a}-I_{b}\right)$ & \\
\hline \multirow{9}{*}{$\begin{array}{l}\text { CaseB } \\
\left(x_{n}>l_{a}\right)\end{array}$} & \multirow{3}{*}{$\begin{array}{c}\text { PointQ } \\
\left(x_{n}=l_{a}+\varepsilon_{01} / \phi_{u}\right)\end{array}$} & Cover & \multirow{2}{*}{ Hognestad } & $t-t_{\text {core }}$ & 0 & $\varepsilon_{01}$ & $\varepsilon_{01}$ & $\varepsilon_{00}$ & \multirow{3}{*}{ (8.Q) } \\
\hline & & Core in wall panel & & $t_{\text {core }}$ & 0 & $\varepsilon_{01}$ & Y & 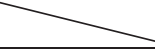 & \\
\hline & & Core in confined area & Saatcioglu & $t_{\text {core }}$ & $\varepsilon_{01}$ & $\varepsilon_{1}$ & $\varepsilon_{1}$ & $\phi_{u}\left(l_{a}-l_{b}\right)+\varepsilon_{01}$ & \\
\hline & \multirow{3}{*}{$\begin{array}{c}\text { PointR } \\
\left(x_{n}=l_{a}+\varepsilon_{1} / \phi_{u}\right)\end{array}$} & Cover & \multirow{2}{*}{ Hognestad } & $t-t_{\text {core }}$ & 0 & $\varepsilon_{01}$ & $\varepsilon_{01}$ & $\varepsilon_{00}$ & \multirow{3}{*}{$(8 . \mathrm{R})$} \\
\hline & & Core in wall panel & & $t_{\text {core }}$ & 0 & $\varepsilon_{01}$ & $\varepsilon_{01}$ & $\varepsilon_{1}$ & \\
\hline & & Core in confined area & Saatcioglu & $t_{\text {core }}$ & 1 & 1 & $\varepsilon_{1}$ & $\phi_{u}\left(I_{a}-I_{b}\right)+\varepsilon_{1}$ & \\
\hline & \multirow{3}{*}{$\begin{array}{c}(\text { CaseB3 }) \\
\left(x_{n}>I_{a}+\varepsilon_{1} / \phi_{u}\right)\end{array}$} & Cover & \multirow{2}{*}{ Hognestad } & $t-t_{\text {core }}$ & 0 & $\varepsilon_{01}$ & $\varepsilon_{01}$ & $\varepsilon_{00}$ & \multirow{3}{*}{ (8.B3) } \\
\hline & & Core in wall panel & & $t_{\text {core }}$ & 0 & $\varepsilon_{01}$ & $\varepsilon_{01}$ & $\phi_{u}\left(x_{n}-l_{a}\right)$ & \\
\hline & & Core in confined area & Saatcioglu & $t_{\text {core }}$ & & & $\phi_{u}\left(x_{n}-l_{a}\right)$ & $\phi_{u}\left(x_{n}-I_{b}\right)$ & \\
\hline
\end{tabular}

ここで, $\varepsilon_{00}$ : 非拘束コンクリートの圧縮強度喪失時のひずみ $\left(=-\frac{17}{3} \varepsilon_{01}+\frac{20}{3} \varepsilon_{085}\right)$ ，その他の表中の文字は Table 4, Figs. 3,22 を参照。

$a \phi_{u}^{2}+b \phi_{u}+c=0, \quad \phi_{u}=\frac{-b-\sqrt{b^{2}-4 a c}}{2 a}$

(A) $a=\frac{3 f^{\prime}{ }_{c c} t_{c o r e}\left(x_{n}-l_{b}\right)^{2}}{40\left(\varepsilon_{1}-\varepsilon_{85}\right)}, b=\frac{f_{c c}^{\prime} t_{c o r e}\left(x_{n}-l_{b}\right)\left(17 \varepsilon_{1}-20 \varepsilon_{85}\right)}{20\left(\varepsilon_{1}-\varepsilon_{85}\right)}-C_{d}, c=\frac{2 f_{c}^{\prime}\left(t-t_{c o r r}\right)\left(-4 \varepsilon_{01}+5 \varepsilon_{085}\right)}{3}+\frac{f_{c c}^{\prime} t_{c o r r} \varepsilon_{1}\left(-31 \varepsilon_{1}+40 \varepsilon_{85}\right)}{120\left(\varepsilon_{1}-\varepsilon_{85}\right)}$

(P) $a=\frac{3 f_{c c}^{\prime} t_{c \text { core }}\left(l_{a}-l_{b}\right)^{2}}{40\left(\varepsilon_{1}-\varepsilon_{85}\right)}, \quad b=\frac{f_{c c}^{\prime} t_{c o r e}\left(l_{a}-l_{b}\right)\left(17 \varepsilon_{1}-20 \varepsilon_{85}\right)}{20\left(\varepsilon_{1}-\varepsilon_{85}\right)}-0.85 \beta f^{\prime}{ }_{c} t l_{a}, \quad c=\frac{2 f^{\prime}{ }_{c}\left(t-t_{c o r e}\right)\left(-4 \varepsilon_{01}+5 \varepsilon_{085}\right)}{3}+\frac{f^{\prime}{ }_{c c} t_{c o r r} \varepsilon_{1}\left(-31 \varepsilon_{1}+40 \varepsilon_{85}\right)}{120\left(\varepsilon_{1}-\varepsilon_{85}\right)}$

(Q) $a=\frac{3 f^{\prime}{ }_{c c} t_{c \text { core }}\left(l_{a}-l_{b}\right)^{2}}{40\left(\varepsilon_{1}-\varepsilon_{85}\right)}, \quad b=\frac{3 f^{\prime}{ }_{c c} t_{c o r e} \varepsilon_{01}\left(l_{a}-l_{b}\right)}{20\left(\varepsilon_{1}-\varepsilon_{85}\right)}+\frac{f^{\prime}{ }_{c c} t_{c o r r e}\left(l_{a}-l_{b}\right)\left(17 \varepsilon_{1}-20 \varepsilon_{85}\right)}{20\left(\varepsilon_{1}-\varepsilon_{85}\right)}-0.85 \beta f^{\prime}{ }_{c} t l_{a}$,

$c=\frac{2 f^{\prime}{ }_{c}^{\prime}\left(t-t_{\text {core }}\right)\left(-4 \varepsilon_{01}+5 \varepsilon_{085}\right)}{3}+\frac{2 f^{\prime}{ }_{c} t_{c o r r} \varepsilon_{01}}{3}+\frac{f^{\prime}{ }_{c c} t_{c o r r} \varepsilon_{1}\left(-31 \varepsilon_{1}+40 \varepsilon_{85}\right)}{120\left(\varepsilon_{1}-\varepsilon_{85}\right)}+\frac{f^{\prime}{ }_{c c} t_{c o r r} \varepsilon_{01}{ }^{2}\left(\varepsilon_{01}-3 \varepsilon_{1}\right)}{3 \varepsilon_{1}{ }^{2}}+\frac{3 f^{\prime}{ }_{c c} t_{c o r r} \varepsilon_{01}{ }^{2}}{40\left(\varepsilon_{1}-\varepsilon_{85}\right)}+\frac{f^{\prime}{ }_{c c} t_{c o r e} \varepsilon_{01}\left(17 \varepsilon_{1}-20 \varepsilon_{85}\right)}{20\left(\varepsilon_{1}-\varepsilon_{85}\right)}-0.85 \beta f^{\prime}{ }_{c} t \varepsilon_{01}$

$a=\frac{3 f^{\prime}{ }_{c c} t_{c o r e}\left(l_{a}-l_{b}\right)^{2}}{40\left(\varepsilon_{1}-\varepsilon_{85}\right)}, \quad b=f^{\prime}{ }_{c c} t_{c o r e}\left(l_{a}-l_{b}\right)-0.85 \beta f^{\prime}{ }_{c} t_{a}$,

(R)

$c=\frac{2 f_{c}^{\prime}\left(t-t_{c o r e}\right)\left(-4 \varepsilon_{01}+5 \varepsilon_{085}\right)}{3}+\frac{2 f_{c}^{\prime} t_{c \text { core }} \varepsilon_{01}}{3}+\frac{f_{c}^{\prime} t_{c o r r} \varepsilon_{1}\left(3 \varepsilon_{1}+34 \varepsilon_{01}-40 \varepsilon_{085}\right)}{40\left(\varepsilon_{01}-\varepsilon_{085}\right)}+\frac{f_{c}^{\prime}{ }_{c} t_{c o r e} \varepsilon_{01}\left(-37 \varepsilon_{01}+40 \varepsilon_{085}\right)}{40\left(\varepsilon_{01}-\varepsilon_{085}\right)}-0.85 \beta f_{c}^{\prime}{ }_{c} t \varepsilon_{1}$

$$
a=\frac{3 t_{c o r e}}{40}\left\{\frac{f_{c}^{\prime}\left(x_{n}-l_{b}\right)^{2}}{\varepsilon_{01}-\varepsilon_{085}}+\frac{f_{c c}^{\prime}\left(2 x_{n}-\left(l_{a}+l_{b}\right)\right)\left(l_{a}-l_{b}\right)}{\varepsilon_{1}-\varepsilon_{85}}\right\}
$$

(B3) $b=\frac{t_{c o r e}}{20}\left\{\frac{f_{c}^{\prime}\left(x_{n}-l_{a}\right)\left(17 \varepsilon_{01}-20 \varepsilon_{085}\right)}{\varepsilon_{01}-\varepsilon_{085}}+\frac{f_{c c}^{\prime}\left(l_{a}-l_{b}\right)\left(17 \varepsilon_{1}-20 \varepsilon_{85}\right)}{\varepsilon_{1}-\varepsilon_{85}}\right\}-C_{d}$,

$$
c=\frac{2 f_{c}^{\prime}\left(t-t_{c \text { cor }}\right)\left(-4 \varepsilon_{01}+5 \varepsilon_{085}\right)}{3}+\frac{f_{c}^{\prime} t_{\text {cor }} \varepsilon_{01}\left(-31 \varepsilon_{01}+40 \varepsilon_{085}\right)}{120\left(\varepsilon_{01}-\varepsilon_{085}\right)}
$$




\section{SOPHISTICATED BENDING ANALYSIS AND SIMPLIFIED ESTIMATION OF ULTIMATE CURVATURE FOR RC SHEAR WALLS WITHOUT BOUNDARY COLUMN} Naoki YAMAMOTO* and Yasushi SANADA**

\footnotetext{
* Former Grad. Stud., Div. of Global Architecture, Graduate School of Eng., Osaka University ** Assoc. Prof., Div. of Global Architecture, Graduate School of Eng., Osaka University, Dr.Eng.
}

Design flexibility of shear walls was extended in Japan by the 2010 revision of Japanese design standard for reinforced concrete buildings ${ }^{1}$, which enabled to design shear walls with no boundary column. Such walls have a potential risk to fail in bending with concrete crushing under high compressive stress, as observed in severely damaged buildings due to the 2010 Chile earthquake ${ }^{2}$. Therefore, a pushover experiment was conducted to perceive basic behavior of a typical shear wall specimen named N(P). Failure mechanism and deformation of this type of wall are discussed through numerical analyses and theoretical performance evaluations as well as the experimental results.

One 1/2.5 scale RC wall specimen with a boundary column only on one side, named $\mathrm{N}(\mathrm{P})$, was prepared to investigate the flexural performance. The depth of confined area was approximately equivalent to the neutral axis depth calculated by Eq. (1). A pushover lateral load was applied to the specimen under a constant axial load of 540 $\mathrm{kN}$, which was approximately $20 \%$ of the compressive strength of the boundary column. However, the shear span to wall length ratio along the boundary column was maintained to be 1.5 .

The specimen failed in a brittle manner with concrete crushing at the bottom. The hinge length at the crushed bottom was approximately 2.5 times the wall thickness, which was much shorter than that at the tensile bottom with a half of wall length. Consequently, the ultimate curvature measured on the compressive cross-section was higher than that on the tensile section.

An elemental experiment was conducted to identify appropriate concrete models to simulate the compressive behavior. Four stress-strain models for concrete: Hognestad, Modified Kent-Park, New RC, and Saatcioglu models, were adopted and compared through cross-sectional analyses of the elemental experiment. Consequently, a combination of Hognestad and Saatcioglu models for unconfined and confined concrete, respectively, could simulate the experimental results well. Moreover, a better agreement was obtained by modifying the Saatcioglu model.

Subsequently, the flexural performance of shear wall specimen was evaluated by a cross-sectional bending analysis, in which non-uniform curvature on the cross-section was considered. The analytical results showed that the flexural performance could be simulated well by the proposed analytical method. Neutral axis depth at the bending-compression failure obtained by the analysis could be roughly evaluated by Eq. (1). Therefore, the other bending analysis was also performed assuming the neutral axis depth to be a constant value at the failure from the previous analysis, which clarified a mechanism at the bending-compression failure of the specimen. The strength deterioration was caused when the external compression applied to the compressive cross-section exceeded the axial resistance.

Based on the failure mechanism above, simple formulas were presented to evaluate the flexural deformation capacity of this type of wall without bending analyses. Good agreements could be obtained between the experimental results of totally 9 specimens and the estimations by the proposed method. It also revealed a key parameter, axial load ratio, affecting the flexural deformation capacity.

In this paper, a bending analysis considering non-uniform curvature was proposed to evaluate the flexural deformation capacity of flexure-dominated walls based on the experimental results, which was verified through a simulation analysis. Moreover, simple formulas for evaluating the deformation capacity based on the failure mechanism were presented and verified showing good agreements with the experimental results. The above discussions provided a key parameter of axial load ratio for the flexure-dominated wall design. 